\title{
REMOVAL OF MERCURY FROM COAL-DERIVED SYNTHESIS
} GAS

Final Report for Base Task 1E

Under DE-FC26-98FT40322

September 2005

U.S. Department of Energy

National Energy Technology Laboratory

Morgantown, West Virginia

By

Western Research Institute

Laramie, Wyoming 


\section{DISCLAIMER}

This report was prepared as an account of work sponsored by an agency of the United States Government. Neither the United States Government nor any agencies thereof, nor any of its employees makes any warranty, expressed or implied, or assumes any legal liability or responsibility for the accuracy, completeness, or usefulness of any information, apparatus, product, or process disclosed or represents that its use would not infringe on privately owned rights. Reference herein to any specific commercial product, process, or service by trade name, trademark, manufacturer, or otherwise does not necessarily constitute or imply endorsement, recommendation, or favoring by the United States Government or any agency thereof. The views and opinions of authors expressed herein do not necessarily state or reflect those of the United States Government or any agency thereof. 


\begin{abstract}
A paper study was completed to survey literature, patents, and companies for mercury removal technologies applicable to gasification technologies. The objective was to determine if mercury emissions from gasification of coal are more or less difficult to manage than those from a combustion system. The purpose of the study was to define the extent of the mercury problem for gasification-based coal utilization and conversion systems.

It is clear that in coal combustion systems, the speciation of mercury between elemental vapor and oxidized forms depends on a number of factors. The most important speciation factors are the concentration of chlorides in the coal, the temperatures in the ducting, and residence times. The collection of all the mercury was most dependent upon the extent of carbon in the fly ash, and the presence of a wet gas desulfurization system. In combustion, high chloride content plus long residence times at intermediate temperatures leads to oxidation of the mercury. The mercury is then captured in the wet gas desulfurization system and in the fly ash as $\mathrm{HgCl}_{2}$. Without chloride, the mercury oxidizes much slower, but still may be trapped on thick bag house deposits. Addition of limestone to remove sulfur may trap additional mercury in the slag.

In gasification where the mercury is expected to be elemental, activated carbon injection has been the most effective method of mercury removal. The carbon is best injected downstream where temperatures have moderated and an independent collector can be established. Concentrations of mercury sorbent need to be 10,000 to 20,000 the concentrations of the mercury. Pretreatment of the activated carbon may include acidification or promotion by sulfur.
\end{abstract}




\section{TABLE OF CONTENTS}

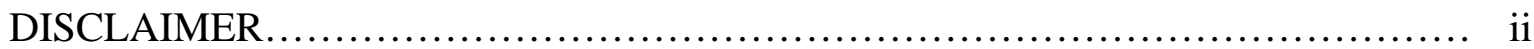

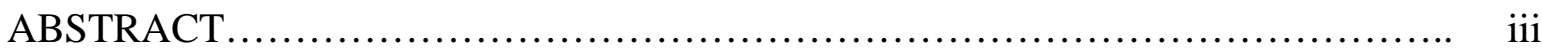

EXECUTIVE SUMMARY ....................................................

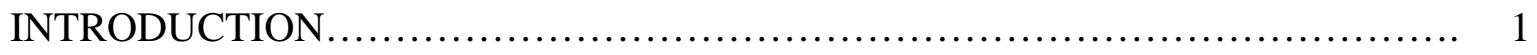

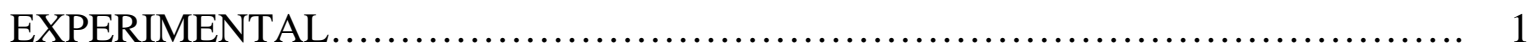

RESULTS AND DISCUSSION............................................... 1

CONCLUSIONS............................................................................ 2

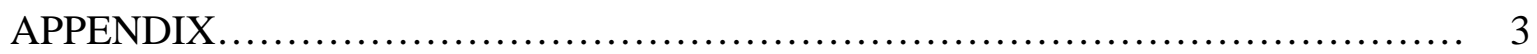




\section{EXECUTIVE SUMMARY}

Gasifiers convert coal into synthesis gas that can then be used to generate electricity, produce fuels and chemicals, or a combination of the two. It is expected that integrated gasification combined cycle (IGCC) processes will have a significant thermodynamic advantage over combustion processes and will allow for increased efficiency for generation of power. Since gasifiers operate at more reducing conditions compared to oxidizing conditions in combustion processes, the species of mercury is the synthesis gas is likely to be different from those encountered in combustion systems. Synthesis gas is likely to be dominated by elemental mercury, which is the most difficult form to remove. In addition, because of the reducing conditions prevalent in gasification systems, many of the sorbents and technologies under development for flue gas streams may not work efficiently under gasifier conditions.

A paper study was completed to survey literature, patents, and companies for mercury removal technologies applicable to gasification technologies. The objective was to determine if mercury emissions from gasification of coal are more or less difficult to manage than those from a combustion system. The purpose of the study was to define the extent of the mercury problem for gasification-based coal utilization and conversion systems.

It is clear that in coal combustion systems, the speciation of mercury between elemental vapor and oxidized forms depends on a number of factors. The most important speciation factors

are the concentration of chlorides in the coal, the temperatures in the ducting, and residence times. The collection of all the mercury was most dependent upon the extent of carbon in the fly ash, and the presence of a wet gas desulfurization system. In combustion, high chloride content plus long residence times at intermediate temperatures leads to oxidation of the mercury. The mercury is then captured in the wet gas desulfurization system and in the fly ash as $\mathrm{HgCl}_{2}$. Without chloride, the mercury oxidizes much slower, but still may be trapped on thick bag house deposits. Addition of limestone to remove sulfur may trap additional mercury in the slag.

In gasification where the mercury is expected to be elemental, activated carbon injection has been the most effective method of mercury removal. The carbon is best injected downstream where temperatures have moderated and an independent collector can be established. Concentrations of mercury sorbent need to be 10,000 to 20,000 the concentrations of the mercury. Pretreatment of the activated carbon may include acidification or promotion by sulfur. 


\section{INTRODUCTION}

Coal is a critical part of the current and future mix of fuels used to produce electricity in the United States. However, coal contains trace amounts of mercury, which are released into the air when it is burned. Some commercially available and commonly used controls for SO2 particulates can additionally capture mercury, but control capabilities vary significantly - from 0 to 90 percent - depending on the coal being burned and the form of the mercury present. Several companies are developing processes and sorbents to remove mercury from flue gas streams.

Gasifiers convert coal into synthesis gas that can then be used to generate electricity, produce fuels and chemicals, or a combination of the two. It is expected that integrated gasification combined cycle (IGCC) processes will have a significant thermodynamic advantage over combustion processes and will allow for increased efficiency for generation of power. Since gasifiers operate at more reducing conditions compared to oxidizing conditions in combustion processes, the species of mercury is the synthesis gas is likely to be different from those encountered in combustion systems. Synthesis gas is likely to be dominated by elemental mercury, which is the most difficult form to remove. In addition, because of the reducing conditions prevalent in gasification systems, many of the sorbents and technologies under development for flue gas streams may not work efficiently under gasifier conditions.

\section{EXPERIMENTAL}

A paper study is proposed to survey literature, patents, and companies for mercury removal technologies applicable to gasification technologies. The objective is to determine if mercury emissions from gasification of coal are more or less difficult to manage than those from a combustion system. The purpose of the study is to define the extent of the mercury problem for gasification-based coal utilization and conversion systems. If it is indeed different from that encountered from that encountered in combustion systems, additional objectives will be to 1) identify potential cosponsors for future jointly sponsored research projects, and 2) identify ideas and concepts that WRI can develop on its own in following years.

\section{RESULTS AND DISCUSSION}

A literature search was completed of the past four years of published material with an emphasis on mercury detection and removal from coal combustion emissions and coal gasification products. Of all the papers listed in the appendix, the majority concern mercury in flue gas and coal combustions systems. This mirrors the available literature and the emphasis on coal fired power plants with respect to mercury emissions. There are a few papers that concern coal gasification, and others which discuss elemental mercury absorption.

It is clear that in coal combustion systems, the speciation of mercury between elemental vapor and oxidized forms depends on a number of factors. The most important speciation factors are the concentration of chlorides in the coal, the temperatures in the ducting, and residence times. The collection of all the mercury was most dependent upon the extent of carbon in the fly 
ash, and the presence of a wet gas desulfurization system. In combustion, high chloride content plus long residence times at intermediate temperatures leads to oxidation of the mercury. The mercury is then captured in the wet gas desulfurization system and in the fly ash as $\mathrm{HgCl}_{2}$. Without chloride, the mercury oxidizes much slower, but still may be trapped on thick bag house deposits. Addition of limestone to remove sulfur may trap additional mercury in the slag.

In gasification where the mercury is expected to be elemental, activated carbon injection has been the most effective method of mercury removal. The carbon is best injected downstream where temperatures have moderated and an independent collector can be established. Concentrations of mercury sorbent need to be 10,000 to 20,000 the concentrations of the mercury. Pretreatment of the activated carbon may include acidification or promotion by sulfur. Suggested best preparation methods are:

- Mix $2 \mathrm{~g}$ of carbon with 0.6 grams of sulfur. Heat to $400^{\circ} \mathrm{C}$ under flowing nitrogen for 6 hours.

- Treat carbon with $6 \mathrm{~N}$ nitric acid for 5 hours at room temperature followed by water wash and $120^{\circ} \mathrm{C}$ dry in air.

\section{CONCLUSIONS}

A literature review was completed which investigates the best methods for mercury removal in gasification environments in comparison to combustion environments. The limited amount of data in the gasification studies suggests that additional work should be completed in that area. The appendix describes the most relevant information available. 


\section{APPENDIX}

\section{Literature review}

\section{Recent advances in mercury removal technology at the National Energy Technology Laboratory, W. O’Dowd, R. Hargis, E. Granite, and H. Pennline, Fuel Processing Tech. 85, 533-548 (2004)}

Combustion, carbon, sulfur promoted carbon, fly-ash, alumina

NETL tested a number of mercury adsorbents at three scales: a bench top fixed bed, a 38 $\mathrm{lb} / \mathrm{hr}$ combustor, and a $500 \mathrm{lb} / \mathrm{hr}$ combustor. Sorbents like activated carbon were injected in the exit ducting and collected in the bag-house. Their conclusions were that activated carbon at ratios greater than 10,000:1 could remove $80 \%$ of mercury, $75 \%$ of which was in oxidized form. Sulfur promotion did not improve the performance of activated carbon. Carbon from fly-ash showed little activity towards mercury adsorption when re-injected. Absorption was much high below $300^{\circ} \mathrm{F}$ than at $400^{\circ} \mathrm{F}$. Absorption seemed to occur primarily in the bag-house and not in the ducting. Granular alumina showed no activity.

Techniques for Mercury Control and Measurement in Gasification Systems, E. Granite, W. King, and $H$. Pennline, $5^{\text {th }}$ International Symposium on Gas Cleaning at High

\section{Temperatures (2002)}

Gasification, carbon, metal oxides, cobalt, chromium

NETL measured the performance of a number of mercury sorbents using nitrogen as a simulated gasification atmosphere through a fixed bed reactor. They cite the advantages of hot gas cleanup of synthesis gas from a coal gasifier as improving the overall efficiency of the gas turbine. The testing emphasized hotter conditions $\left(>400^{\circ} \mathrm{F}\right)$ for testing sorbents. Mixed oxide sorbents such as $\mathrm{Co}_{2} \mathrm{O}_{3}-\mathrm{Al}_{2} \mathrm{O}_{3}$ and $\mathrm{Cr}_{2} \mathrm{O}_{3}-\mathrm{Al}_{2} \mathrm{O}_{3}$ have good results at $400^{\circ} \mathrm{F}$. Most activated carbons did not do well at these temperatures. The frustrating part of this paper is the listing of several sorbents doing very well up to $500^{\circ} \mathrm{F}$ temperature, but only describing the sorbent as Sorbent X or Sorbent Y. Manganese, copper, silicon and nickel oxides showed no mercury absorption activity as did PbSe. Molybdenum sulfide had modest activity.

\section{Covering all the bases, G. Offen, N. Shick, R. Chang, P. Chu, C. Dene, and R. Rhudy,} Power, 148, 8, 38-42 (2004)

\section{Combustion, coal types, general info, TOXECON}

This EPRI paper is an overview of mercury control in coal-fired power plants. They make the comment that a combination of selective catalytic reduction (SCR) intended for $\mathrm{NO}_{\mathrm{x}}$ control and wet flue gas desulfurization (FGD) has been shown to remove up to $90 \%$ of mercury from flue gas. The SCR aids in oxidizing the mercury to soluble forms that dissolve in the wet scrubber. Activated carbon injection (ACI) also can remove $90 \%$ of mercury. Costs are suggested to run up to $\$ 3.5$ million per year for a $500 \mathrm{MW}$ plant using injection rates of $10 \mathrm{lbs}$ of carbon per million cubic feet of flue gas. Two additional problems are that electrostatic precipitators (ESP) may not be sized to handle the additional load of solids including the injected carbon, and that carbon-contaminated fly-ash is not suitable for cement production. The TOXECON process uses post ESP or bag-house carbon injection and a secondary bag-house to capture the carbon. The capitol cost of Toxecon is suggested as \$45 to \$55 per kilowatt. Using a single ESP and using different collecting fields for carbon and fly-ash may reduce the costs. 
Halide addition is suggested to improve mercury oxidation during use of Powder River Basin (PRB) coal. Blending eastern sub-bituminous coal and PRB coal may produce similar results. Amended silicates and sodium tetra-sulfide are mentioned but with little data to support their use.

Using Wet FGD Systems to Adsorb Mercury, S. Renninger, G. Farthing, S. Ghorishi, C. Teets, and J. Neureuter, Power 148, 8, 44-49

Combustion, FGD, SCR, NaHS, chloride

Babcock and Wilcox used full-scale power plant testing to show that adding NaHS to the wet scrubber liquid increases the absorption of mercury and prevents reemission of elemental mercury through reduction by metal ions in solution. Chloride content in the coal is listed as a key component to the oxidation of mercury and the success of FGD for mercury removal.

\section{A Tale of Two Processes, J. Duncan, Power 148, 8, 50-53}

Combustion, electro-catalytic oxidation (ECO), photo-chemical oxidation (PCO)

Powerspan Corp. is using two technologies to increase mercury oxidation prior to absorption. No technical data is given for electro-catalytic oxidation. Photo-chemical oxidation is described as a process in which $254 \mathrm{~nm}$ UV light is beamed through the exit ductwork to oxidize mercury to absorbable chloride species. Power consumption is the biggest cost for PCO.

Mercury Removal Via Wet ESP, J. Reynolds, Power 148, 8, 54-59

Combustion, wet ESP, PEESP (plasma enhanced ESP)

Clean Air Technologies has conducted a study using a FGD system followed by a wet electrostatic precipitator to remove sulfur and $\mathrm{PM}_{2.5}$ particulates. They claim that 40 to $80 \%$ of mercury from combustion of eastern sub-bituminous coals is oxidized and only $10 \%$ to $20 \%$ from western sub-bituminous and lignite coals is oxidized. The WESP was effective at removing oxidized mercury but ineffective with elemental mercury. The plasma coronal discharge, designed to improve mercury oxidation, was defeated by the presence of NO and CO, which were oxidized in preference to the small amounts of mercury present.

\section{Pahlman Process Shows Promise, C. Hammel, Power 148, 8, 60-63}

Combustion, $\mathrm{MnO}_{2}$

Enviroscrub Technologies produces a sorbent primarily made of $\mathrm{MnO}_{2}$ that purportedly removes $\mathrm{SO}_{\mathrm{x}}, \mathrm{NO}_{\mathrm{x}}$ and mercury as well. The process involves spraying, collection, then recycling the $\mathrm{MnO}_{2}$ via washing and oxidizing steps.

\section{Sorbent Injection Making Progress, M. Durham, Power 148, 8, 64-67}

Combustion, carbon, DARCO-FGD, KNX, halide, Norit Americas

ADA Environmental Solutions describes testing of carbon based injection processes (ACI) for mercury absorption. No mention is made between differences in oxidized and elemental mercury adsorption, and the numbers seem very high even at modest injection rates (0.66lb to 1.2lb/MMacf). A coal additive called KNX from Alstom Power is mentioned though not described. 
Photochemical Removal of Mercury from Flue Gas, E. Granite and H. Pennline, Industrial Eng. Chem. Res., 41 5470-5476

This paper describes the NETL bench-top study of the use of UV at 253nm to oxidize mercury in the presence of oxygen and sulfur dioxide. UV at $360 \mathrm{~nm}$ had no effect on mercury oxidation. The oxidation rate dropped off greatly from $280^{\circ} \mathrm{F}$ to $350^{\circ} \mathrm{F}$. The sulfur dioxide acted to shield the mercury from adsorption at intensities near $0.5 \mathrm{~mW} / \mathrm{cm}^{2}$, so the intensity was increased to 1.4 $\mathrm{mW} / \mathrm{cm}^{2}$. A mechanism using oxygen radicalization and ozone formation is proposed. It is not mentioned whether in a carbon monoxide / hydrogen environment mercury would oxidize and remain oxidized.

An Interpretation of flue-gas mercury speciation data from a kinetic point of view, J Wang, B. Clements, and K. Zanganeh, Fuel 82, 1009-1011 (2003)

This simplified approach to the speciation of mercury in flue-gas is based on time, temperature and chloride content in the coal. Thermodynamics says that above $625^{\circ} \mathrm{C}$ all mercury should be elemental, while below $450^{\circ} \mathrm{C}$, all mercury should be $\mathrm{HgCl}_{2}$ providing that chloride concentration in the coal is many times that of mercury. Although the paper does not discuss it in any detail, the implication is that longer dwell times at the correct temperature range should lead to higher mercury capture by wet gas desulfurization methods.

Importance of activated carbon's oxygen surface functional groups on elemental mercury absorption, Y. Li, C. Lee, and B. Gullett, Fuel 82, 451-457 (2003)

Activated carbons were treated to affect surface oxygen functionality. Nitrogen at $925^{\circ} \mathrm{C}$ destroyed the carbon's mercury absorption capability. Air oxidation at $420^{\circ} \mathrm{C}$ also reduced the mercury absorption ability of the carbon. Nitric acid soaking at room temperature at $6 \mathrm{~N}$ for 5 hours followed by water washing and $100^{\circ} \mathrm{C}$ drying greatly increased elemental mercury adsorption at $125^{\circ} \mathrm{C}$ in nitrogen.

An Investigation of mercury Emission from FBC Systems Fired with High-Chlorine Coals, K. Liu, Y. Gao, J. Riley, W. Pan, A. Mehta, K. Ho, and S. Smith Energy and Fuels, 15, 1173-1180 (2001)

Combustion, chloride, PVC

This study at Western Kentucky University examined the effects of high chloride content coals on mercury speciation and collection during combustion. The amount of oxidized mercury collected with the fly ash was in proportion with the chloride content of the coals, which varied from 260 to $4000 \mathrm{ppm}$. Little or no elemental mercury was found for high chloride coals. The presence of oxygen during combustion was thought to reduce the temperature of the mercury emission to $300^{\circ} \mathrm{C}$ and below. Waste PVC was used as a free chloride source for low chloride coals.

Effects of Sulfur Impregnation Temperature on the Properties and Mercury Adsorption Capacities of activated Carbon Fibers, H. His, M. Rood, M. Rostam, S. Chen, and R. Chang, Environ. Sci. Tech. 35, 2785-2791 
The ability of sulfur-impregnated carbon to absorb elemental mercury was improved by heat treatment at $400^{\circ} \mathrm{C}$ in nitrogen. This was due to an increase in appropriate porosity of the sorbent and the type of sulfur containing surface functionalities. Mercury absorption was only tested. 